\title{
THE PLAINTIFFS AND THEIR FAMILIES
}

\section{Robinson v. Cahill}

Ernestine Betty Robinson*

Her children: Patricia, Gwen, Larry (Tank), Tony, Kenneth*, Joan, Lydia, and Saundra

Abbott v. Burke

\section{Camden}

Luci and Howard Abbott

Their son: Raymond*

Blanca Figueroa

Her children: Vivian*, Orlando*, Frances*, Hector*, and Arlayne*

Lola Moore

Her children: Lynnette and Michael Hadley*

Nezettia Stevens and Henry Stevens Sr.

Their son: Henry Jr.*

\section{East Orange}

Mattie James

Her children: Julian (Bunny), Caroline*, and Jermaine* Lynn Waiters

Her children: Dorian* and Khudayja*

\section{Irvington}

Gladys Knowles and Guy Knowles Sr.

Their children: Guy Jr.*, Cristina*, and Daniel* 


\section{Jersey City}

Lucila and Justo Diaz

Their daughter: Liana*

Tommi and Eddie Stephens

Their children: Leslie* and LaMar*

Patricia Watson and James Hargrove

Their daughters: Zakia* and Aisha Hargrove*

*plaintiff 


\section{Other People's Children}


